\title{
Relating job satisfaction and organisational commitment: The moderating and mediating roles of positive individual strengths
}

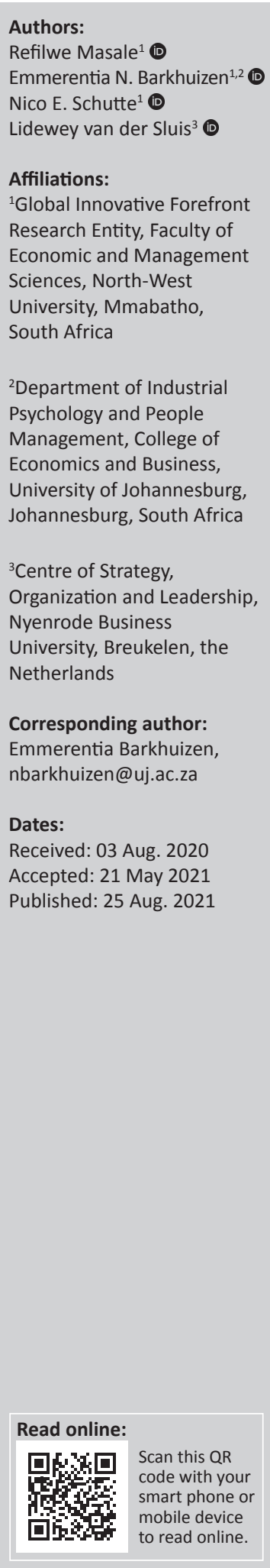

Orientation: This rapidly changing world requires local government institutions to focus on positive work-related states to enhance quality service delivery.

Research purpose: The main objective of this article was to explore how individual traits and psychological strengths (i.e. adult state hope, meaning in life and work locus of control) moderate or mediate the relationship between job satisfaction and organisational commitment in a Botswana local government institution.

Motivation for the study: The emergence of the coronavirus disease 2019 (COVID-19) pandemic forced employers to rely on the foundations of positive organisational psychology to navigate employee well-being more effectively during times of unprecedented crisis.

Research approach/design and method: A quantitative research approach was followed. An adapted Minnesota job satisfaction questionnaire, organisational commitment questionnaire, adult state hope scale, meaning in life questionnaire and work locus of control scale were distributed to public sector officials of a Botswana local government institution $(N=405)$.

Main findings: Adult state hope, meaning in life and work locus of control partially mediated the relationship between job satisfaction and organisational commitment.

Practical/managerial implications: Management should create a workplace culture that can promote job satisfaction amongst public officials. Job satisfaction influences essential individual and outcomes organisational in public sector institutions.

Contribution/value-add: This research is original and provides evidence for the use of positive psychology constructs (i.e. adult state hope, meaning in life and work locus of control) combined with job satisfaction to enhance organisational commitment.

Keywords: adult state hope; job satisfaction; locus of control; meaning in life; organisational commitment.

\section{Introduction}

Botswana local government institutions play an essential role in promoting sustainable economic growth through productive and decent employment practices (Musekiwa \& Mandiyanike, 2017). Public officials are required to deliver legitimate and value-added services to instil public trust (Andersson, 2019). Unfortunately, local government institutions are persistently challenged by ineffective service delivery, not reaching its desired impact in the broader society (Tshukudu, 2020). The extent of Botswana local authority's service expectations contributes to escalating public officials' work demands without the necessary service infrastructure to support them in their daily tasks (Samboma, 2019). Employees are further dissatisfied and demotivated by inadequate public performance management systems (Bester \& Hofisi, 2020) and insufficient total reward models (Tshukudu, 2020). Consequently, staff members are at risk of developing high levels of stress and burnout, resulting in detachment from their jobs and institutions (Dubale et al., 2019; Westmoreland et al., 2017). High burnout and organisational detachment undermine public service efficiency (Eldor, 2018).

The main objective of this research was to determine how individual traits and psychological strengths (i.e. adult state hope, meaning in life and work locus of control) moderate or mediate the

How to cite this article: Masale, R., Barkhuizen, E.N., Schutte, N.E., \& Van der Sluis, L. (2021). Relating job satisfaction and organisational commitment: The moderating and mediating roles of positive individual strengths. SA Journal of Industrial Psychology/SA Tydskrif vir Bedryfsielkunde, 47(0), a1832. https://doi.org/10.4102/sajip.v47i0.1832

Copyright: ( 2021. The Authors. Licensee: AOSIS. This work is licensed under the Creative Commons Attribution License. 
relationship between job satisfaction and organisational commitment at a selected Botswana local government institution. Job satisfaction is an essential job-related behaviour to study because of its consistent association with public sector employees' service performance in Botswana (Mkubwa, 2010). Tella, Ayeni and Popoola (2007) proposed that commitment is promoted where there is a spirit of cooperation and employee satisfaction. Organisational commitment reflects the employee attitudes that translate into public sector performance (Berberoglu, 2018). According to Moynihan and Pandey (2007), managers find it challenging to motivate employees in the public sector as institutional dynamics restrict the ability to recognise and reward performance. Akhras (2019) believed that hope can reengineer organisational structures and generate new vibrant corporate cultures that foster positive behaviour. Meaningfulness can further contribute to cognitive, emotional, behavioural and economic benefits for employees and public sector institutions (Keleş \& Findikli 2016; Tummers \& Knies, 2013). According to Fagbola and Popoola (2015), management awareness of employees' work locus of control in the public sector can help determine their organisational commitment levels.

This research is motivated by the current global drive, emphasising putting 'people first at work' (Volini et al., 2019). The emergence of the coronavirus disease 2019 (COVID-19) pandemic further forces employers to rely on the foundations of positive organisational psychology and occupational rehabilitation theory to navigate employee well-being more effectively during times of unprecedented change (Giorgi, Lecca, \& Alessio, 2020; Shaw et al., 2020). According to Waters et al. (2021), the building of positive processes and capacities can strengthen employees' future mental health during an intense crisis such as COVID-19. Given the significance of job satisfaction and organisational commitment for public sector performance, a study of how adult state hope, meaning in life and work locus of control can influence the relational direction between these variables is imperative.

This research attempts to answer the following research questions:

- What is the moderating-mediating role of adult state hope in the relationship between job satisfaction and organisational commitment?

- What is the moderating-mediating role of meaning in life in the relationship between job satisfaction and organisational commitment?

- What is the moderating-mediating role of work locus of control in the relationship between job satisfaction and organisational commitment?

This research article is structured as follows. Firstly, a literature review is presented on the constructs explored in this study and their possible inter-relationships. Secondly, there is a description of the research design adopted for the study. Then, the study results, as well as a discussion of the results, are presented. Finally, the article concludes with recommendations for practice and future research.

\section{Literature review}

\section{Relating job satisfaction and organisational commitment}

Job satisfaction remains one of the most frequently researched attitudinal variables. The two most commonly used definitions of job satisfaction are presented by Locke (1976) and Spector (1997). Spector (1997, p. 1342) followed a psychological approach towards job satisfaction by defining the concept as 'the pleasurable emotional state resulting from the appraisal of one's job as achieving or facilitating the achievement of one's job values'. Locke (1976, p. 2) provided a more simplistic definition by referring to job satisfaction as 'the extent to which people like (satisfaction) or dislike (dissatisfaction) their jobs'. For this research, we define job satisfaction as the employees' perceived evaluation of their job, underpinned by their values, needs and expectations (Buitendach \& Rothmann, 2009). According to Nalem (2015), factors influencing public councillors' job satisfaction include recognition, career advancement, sense of achievement and recognition. Other studies showed that talent management practices in general (Magolego, 2013; Mpofu, 2013) and salaries, promotional opportunities and training programmes contributed to employees' level of job satisfaction in local municipalities (Mvelase, 2018).

In line with Meyer and Allen (1991), we define organisational commitment as a multidimensional construct consisting of affective, normative and continuance commitment (Meyer \& Allen, 1991). Affective commitment occurs when an employee is affectionately attached to the organisation and identifies with its objectives. Continuance commitment refers to when an employee is ready to be part of the organisation and apply his or her skills on the job. Normative commitment exists where an employee feels that he or she has to be part of the organisation. According to Morris (2013), organisational commitment and loyalty occur when public institutions create an attractive work environment. Highly committed public sector staff are the backbone of institutions and fundamental for the success of their respective institutions (Thabo, Nkhukhu-Orlando, Wilson, \& Forcheh, 2018).

The relationship between job satisfaction and organisational commitment is well established (Rakowska, Valdes-Conca \& Juana-Espinosa, 2014). According to Sattar (2014), employee involvement and commitment are dependent on the level of job satisfaction. Eslami and Gharakhani (2012) found that job satisfaction indicators (i.e. promotions, personal relationships and favourable conditions) positively affect organisational commitment. Morris (2013) opined that enhanced job satisfaction for public sector employees increases the chances of retaining staff and creating a pool of talented individuals. Research by Khan and Jan (2014) showed that satisfaction improves commitment and reduces turnover amongst council employees. Baruti (2017) found that job satisfaction 
predicted the organisational commitment of public sector employees in Botswana.

H1: Job satisfaction is positively related to organisational commitment.

\section{Job satisfaction and organisational commitment: Moderation and mediating variables}

\section{Job satisfaction, adult state hope and organisational commitment}

According to Mukherjee and Sharma (2020), a great deal of vagueness still exists around the definition of hope in the workplace context. Snyder and colleagues coined two types of hope: adult dispositional hope (Snyder, Irving, \& Anderson, 1991) and adult state hope (Snyder et al., 1996). Snyder et al. (1991, p. 128) defined adult hope as 'a positive motivational state that is based on an interactively derived sense of success agency (i.e. goal-directed energy) and pathways (planning to meet goals)'. Individuals with high dispositional hope approach job-related barriers as challenges they can overcome by navigating alternative pathways to achieve their goals (Snyder, 2000). Similarly, Luthans, Avolio, Avey and Norman (2007) defined hope as individuals' perceived capability to motivate themselves successfully through avenues to research their desired goals. Hope can be a positive motivational resource (Mishra, Putnaik, \& Mishra, 2016) and a process through which an individual overcomes obstacles in pursuing a specific purpose (Cetin \& Basim, 2011). Snyder et al. (1996) defined adult state hope as a goaldirected individual strength that can be applied in any given moment or situation. Hope is, therefore, a multifaceted attribute that often occurs during adverse circumstances (Bruininks, 2012).

The available literature showed that hope is mainly used as a moderator or mediator in the context of children, students, young adults and the broader community (see Dwivedi \& Rastogi, 2017; Gungor, 2016; Khan et al., 2020). Other studies focused on the mediating and moderating effects of hope as a psychological capital construct between workplace antecedents and individual outcomes (Choi \& Kang, 2015). Brouze (2013) found that psychological capital (including hope) moderated the relationship between workload and cynicism and mediated the relationships between job autonomy, supervision support, career advancement and the job attachment construct of work engagement.

The vast majority of research studies seem to approach the job satisfaction-hope relationship from the direction that hope contributes to job satisfaction as a psychological disposition. Luthans et al. (2008) found that positive psychological capital (consisting of hope, resilience, optimism and efficacy) is positively related to employee's performance, satisfaction and commitment. Likewise, the relationship between psychological hope and organisational commitment is well established. Hope has shown to be positively related to normative (Ozag, 2006), affective (Bressler, 2010) and continuance commitment (Pillay, Buitendach, \& Kanengoni, 2014).
Yet, a true perspective on the moderating and mediating capacity of adult state hope between work-related factors and individual and organisational outcomes is lacking. In line with the definitions of Snyder et al. $(1991,1996)$, the researchers in this study approach adult hope as a focused work-related trait that can either act as a resilience factor (i.e. moderator) or a catalyst (mediator) in the relationship between job satisfaction and organisational commitment, depending on the nature of satisfaction that the individual experiences with job-related matters in the workplace. We argue that hope can have a buffering effect between job satisfaction and organisational commitment. Individuals who are motivated (i.e. agency) and able to navigate their job goals effectively (i.e. pathways) can overcome job barriers and still display a sense of attachment to their organisation. Furthermore, individuals who experience high levels of job satisfaction will be more motivated to create avenues to achieve their work and career goals and be more committed to their organisation. In the latter context, we argue that hope mediates the relationship between job satisfaction and organisational commitment. Thus, the following hypotheses are proposed:

H2a: Job satisfaction is positively related to adult state hope.

H2b: Adult state hope is positively related to organisational commitment.

H2c: Adult state hope moderates the relationship between job satisfaction and organisational commitment.

H2d: Adult state hope mediates the relationship between job satisfaction and organisational commitment.

\section{Job satisfaction, meaning in life and organisational commitment}

The concept of meaning in life is still a work in progress. According to Martela and Steger (2016, p. 531), three aspects need to be considered in refining the concept of meaning in life: coherence (i.e. 'a sense of comprehensibility and one's life making sense'), purpose (i.e. 'a sense of core goals, aims and direction in life') and significance (i.e. 'a sense of life's inherent value and having a life worth living'). Researchers highlight the importance of integrating the concept of 'meaning' with both the personal and work domains. Geldenhuys, Laba and Venter (2014) viewed meaning as a concept linked to a person's existence and include the workplace as an essential part of an individual's life. Similarly, Ivtzan, Sorensen and Halonen (2013) believed that meaningfulness should consist of aspects relating to the individual's work and general lives instead of only focusing on workplace well-being.

The questions of interest in this study are whether meaning in life can act as a moderator or mediator in the relationship between job satisfaction and organisational commitment. The relationship between meaningfulness and job satisfaction appears to be reciprocal, depending on the nature and context of meaningfulness. Research that viewed meaningfulness from a work-related approach found that the meaning of work predicted employees' job satisfaction (see Zheng, Wu, \& Graham, 2019). Rothausen and Henderson (2018) coined 
meaningful job satisfaction to broaden the scope of job satisfaction to contextualise meaning in different areas of an employee's life, such as the society, work and the individual itself. According to Nair and Manikandan (2013), employees who can embrace a meaningful life are more likely to be organisationally committed. Maharaj and Schlechter (2007) showed that both meaning in life and meaningful work were significantly positively related to organisational commitment.

The majority of research studies to date have focused on the moderating-mediating role of meaning in the workplace context. Consequently, limited research is available on meaning in life as an enabling or buffering construct in the workplace domain. Fletcher and Schofield (2019) found some support that meaning in life mediated the relationship between work meaningfulness and job-work engagement. The mediation effect was dependent on micro-level aspects (i.e. sustaining motivation), meso-level factors (i.e. line manager roles) and macro-level determinants (i.e. sociopolitical environment). Jada, Jena and Pattnaik (2015) found support for meaning in life as a mediator between hope and organisational commitment amongst IT specialists.

The intervening roles of meaning in life have proven useful in abnormal psychology contexts. Schnell and Krampe (2020) found that meaning in life as a psychological resource moderated the effect of acute COVID-19-related stress on general mental health. In the same study, the crisis of meaning mediated the relationship between COVID-19 stress, anxiety and depression. Yang et al. (2019) found moderating and mediating effects for meaning in life and searching for meaning in the relationship between mindfulness and depressive symptoms. From the above findings, one can deduce that the nature and strength of an individual's meaning in life can have a buffering or spill-over effect between challenging situations and individual outcomes. Thus, the following hypotheses are proposed:

H3a: Job satisfaction is positively related to meaning in life.

H3b: Meaning in life is positively related to organisational commitment.

H3c: Meaning in life moderates the relationships between job satisfaction and organisational commitment.

H3d: Meaning in life mediates the relationship between job satisfaction and organisational commitment.

\section{Job satisfaction, work locus of control and organisational commitment}

Locus of control emerged during the 1960s and includes internal and external facets of a person (Cobb-Clark, 2014). Internal locus of control refers to an individual's perceived control over outcomes in their life. In contrast, individuals with an external locus of control rely on the chance of convincing others to achieve goals (Reknes, Viscockaite, Liefooghe, Lovakov, \& Einarsen, 2019). Work locus of control (WLOC) refers to how employees believe they can control their work environment (Shannak \& Al-Taher, 2012). According to Fitzgerald and Clark (2013), employees with an external WLOC are characterised as taking less responsibility for clients, are less likely to make successful employment decisions and are less confident about their knowledge and skills than those with a high internal WLOC. Accordingly, locus of control is a diagnostic variable that shows an individual's perception of the environment and position, role, rate and influence of a person in the success and failures of life events (Pourhoseinzadeh et al., 2017).

The majority of research studies to date have approached the job satisfaction-locus of control relationship from the perspective that locus of control significantly influences the perceived level of job satisfaction amongst individuals (Gangai, Mahakud, \& Sharma, 2016). In the present study, work locus of control is regarded as a personality trait (Reknes et al., 2019) that can play an intervening role between employees' job satisfaction and work-related outcome variables, such as organisational commitment. Locus of control has consistently been related to employees' organisational commitment (Rank \& Puapradit, 2017). According to Erwin (2011), a person with a strong internal locus of control will subsequently have a high level of commitment. Chhabra (2013) showed that the locus of control moderated the relationship between job satisfaction and organisational commitment. The effect was more substantial for individuals with an internal locus of control than those with a higher external locus of control. Other studies have shown that a lack of involvement and control over one's environment can mediate the relationship between job satisfaction and organisational commitment (Mendoza, 2019). Thus, we propose the following hypotheses:

H4a: Job satisfaction is positively related to work locus of control.

H4b: Work locus of control is positively related to organisational commitment.

H4c: Work locus of control moderates the relationship between job satisfaction and organisational commitment.

H4d: Work locus of control mediates the relationship between job satisfaction and organisational commitment.

\section{Research design}

The researchers applied a quantitative research approach by distributing surveys to collect the data. A cross-sectional research was used to determine the inter-relationships between the variables, that is, job satisfaction, adult state hope, meaning in life, work locus of control and organisational commitment, over a shorter period (Field, 2019). This research falls within the positivist research paradigm, which 'emphasise $[s]$ that genuine, real and factual happenings could be studied and observed scientifically and empirically' (Aliyu, Bello, Kasim, \& Martin, 2014, p. 83). The positivist paradigm therefore supports the quantitative nature of the study.

\section{Respondents}

Employees of a selected Botswana local government institution were considered as the target population for this study. The main researcher distributed 650 questionnaires of which 405 
completed questionnaires were returned, providing a response rate of $62.30 \%$. The respondents were primarily women $(55.30 \%)$, married $(51.34 \%)$ and Setswana-speaking people (99.80\%). Most of the participants were aged between 40 and 49 years $(66.40 \%)$, have a Certificate and Diploma as their highest level of educational qualification (48.63\%) and were employed on operational level (39.76\%). The participants mainly had work experience of between 14 and 29 years (39.76\%). About 71.60\% of the respondents did not have an opportunity to be promoted over the last 5 years. The vast majority of the respondents (90.6\%) worked between 31 and $40 \mathrm{~h}$ per week.

\section{Measuring instruments}

The following measuring instruments are used in this study:

- Minnesota job satisfaction questionnaire (MSQ): An adapted and shortened version of the Minnesota job satisfaction questionnaire (Buitendach \& Rothmann, 2009) measured the respondents' job satisfaction. The MSQ covers 13 aspects relating to the respondents' work (example includes 'I am satisfied that I am fairly compensated for the amount of work that I do'). The response scale ranged from strongly disagree (1) to strongly agree (6). All items are added to obtain a total score. Buitendach and Rothmann (2009) obtained an internal consistency of $\alpha=0.86$ for the adapted version. According to the guidelines of the original developers of the MSQ (see Weiss, Dawis, England, \& Lofquist, 1967), a percentile score of $75 \%$ and higher indicates a high degree of job satisfaction. In contrast, a percentile score of $25 \%$ and lower will indicate a low level of satisfaction (see Weiss et al., 1967). Scores in the middle range, that is, percentile $\% \geq 25 \% \leq 75 \%$, indicate an average level of job satisfaction. In this study, factor analyses revealed one underlying factor for job satisfaction (measure of sample adequacy [MSA] $=0.946$, total variance explained $=75.05 \%$, mean $=2.77$, range between median and 75th percentile) with a reliability of $\alpha=0.96$. In line with Weiss et al. (1967) guidelines, the respondents displayed average levels of job satisfaction.

- Organisational commitment questionnaire: Meyer and Allen's (1991) organisational commitment questionnaire is used to measure organisational commitment. The questionnaire consists of 15 items and measures three factors: affective (i.e. 'I really care about the fate of this organisation'), normative (i.e. 'I really care about the fate of this organisation') and continuous commitment (i.e. 'It would take a lot of change in my present circumstances to cause me to leave this organisation' (Meyer \& Allen, 1991). Data were collected on a six-point Likert scale ranging from strongly disagree (1) to strongly agree (6). Lesenyeho (2017) obtained an internal consistency of $\alpha=$ 0.86 . High scores represent a high level of organisational commitment (Meyer \& Allen, 1991). In the present study, factor analyses revealed two underlying factors for organisational commitment $(\mathrm{MSA}=0.94$, total variance explained $=75.05 \%$ ) with a reliability of $\alpha=0.91$ for affective commitment (mean $=3.21$; range between median and 75th percentile) and $\alpha=0.94$ for normative commitment $($ mean $=2.74$; range between median and 75th percentile). In line with Meyer and Allen's (1991) recommendations, employees displayed average affective commitment levels and average levels of normative commitment. A second-order factor analysis was carried out to create the variable 'organisational commitment' (variance explained $=85.33 \%$ ) for moderating-mediating analyses.

- Adult state hope scale: An adapted version of the adult state hope scale of Snyder et al. (1996) was used to assess the respondents' level of hope in the work context. This scale consists of six items and measures two dimensions: agency (i.e. goal-directed energy - 'I am hopeful that I can meet the goals that I have set for myself') and pathways (i.e. planning to accomplish goals - 'I am hopeful that I can find ways to deal with problems' (Snyder et al., 1996). Responses are collected on an adjusted six-point Likert scale ranging from strongly disagree (1) to strongly agree (6). The hope levels of respondents are determined by adding the scores of individual responses. No norms exist for this scale as scores fluctuate based on circumstances (see Snyder et al., 1996). Snyder et al. (1991) found acceptable internal consistencies ranging from $\alpha=0.79$ to 0.95 . The factor analyses resulted in one factor for the adult hope scale $(\mathrm{MSA}=0.91$, total variance explained $=91.92 \%$, mean $=3.41$, range between median and 75th percentile) with a reliability of $\alpha=0.98$. In line with Snyder et al.'s (1996) work, respondents in the current study displayed a moderate adult state hope level.

- Meaning in life questionnaire: The 10-item meaning in life questionnaire (MLQ) of Steger et al. (2006) assessed the presence of meaning in the respondents' life and the search for meaning respondents (i.e. 'I have discovered a satisfying life purpose'). Responses are collected on an adjusted six-point Likert scale ranging from strongly disagree (1) to strongly agree (6). Steger et al. (2006) found acceptable consistencies for this questionnaire, ranging from $\alpha=0.82$ to 0.87 . The MLQ does not have cut scores but rather measures meaning in life across the entire spectrum of human functioning (see Steger et al., 2006). The factor analyses in the present study resulted in one factor for the MLQ (MSA $=0.92$, total variance explained $=80.52 \%$, mean $=3.530$, range between median and 75th percentile) with a reliability of $\alpha=0.97$. Based on Steger et al. (2006), the respondents experienced average levels of meaning in life.

- Work locus of control scale: The work locus of control scale (WLCS) (Spector, 1988) is used to measure the internal (i.e. 'if you know what you want out of a job, you can find a job that gives it to you') and external locus of control (i.e. 'to make a lot of money you have to know the right people') of the respondents. This questionnaire consists of 16 items and measures responses on a sixpoint Likert scale ranging from strongly disagree (1) to strongly agree (6). Spector (1988) obtained internal consistencies ranging from 0.75 to 0.85 for the instrument. High scores present a high level of work locus of control. In the present study, factor analyses revealed two underlying factors for work locus of control (MSA $=0.94$, total variance explained $=61.98 \%$ ) with a reliability of 
$\alpha=0.89$ (mean $=3.61$, range between median and 75th percentile) for internal locus of control and $\alpha=0.91$ for external locus of control (mean $=2.98$, range between median and 75th percentile). A second-order factor analysis was performed to develop a one-factor solution for the WLCS (variance explained $=65.30 \%$ ).

\section{Research procedure}

Permission to conduct the study was obtained from the relevant local government authority. The main researcher had several meetings with local government management to explain the purpose and process of the research. The hardcopies of the questionnaires were distributed to the respondents through supervisors and heads of departments of the local government institution. The researchers obtained ethical approval from North-West University before its commencement. Participation in the study was voluntary and confidentiality was maintained at all times.

\section{Statistical analysis}

Statistical analyses were carried out using Statistical Package for Social Sciences (SPSS) (SPSS Inc., 2021). The data analysis techniques included descriptive statistics, exploratory factor analysis, reliability analysis and multiple regression analysis. Cohen's (1988) guideline of $\alpha \geq 0.70$ was used to determine the reliabilities of underlying factors of the measuring instruments. The results of the Pearson correlation analyses were interpreted using the guidelines of Cohen (2008): $r \leq 0.29, p \leq 0.05$ (statistically significant relationship), 0.30 $\leq r \leq 0.49, p \leq 0.05$ (practically significant, medium effect) and $r \geq 0.50, p \leq 0.05$ (practically significant, large effect).

Multiple regression analysis were used to determine the mediating and moderating effects of adult state hope, meaningfulness and work locus of control between job satisfaction and organisational commitment. The four steps of Baron and Kenny (1986) were followed to determine the moderating effect of the variables (i.e. adult state hope, or meaningfulness and work locus of control) on job satisfaction and organisational commitment. Both the predictor and moderator variables were centred to reduce multicollinearity (Cohen, 2008). Based on the recommendations of Baron and Kenny (1986), follow-up mediation analyses were applied where moderation analyses yielded a non-significant result.
The moderation analyses consist of four steps: (1) testing the predictive relationship between the predictor and dependent variable, (2) testing the predictive relationship between the moderator and dependent variable, (3) testing the predictive relationship between the predictor, moderator and dependent variables and lastly (4) adding the interaction variable (predictor $\times$ moderator variable) with the predictor, moderator and dependent variables (see Baron \& Kenny, 1986). Baron and Kenny (1986) further advised that moderation occurs when the interaction variable is significant. For mediation analyses, steps 1-3 of the moderation analyses are repeated. For complete mediation to occur, the relationships between the variables for the first three steps must be significant and the independent variable should no longer affect the depending variable after mediation (Baron \& Kenny, 1986). Partial mediation occurs when the independent variable's influence on the dependent variable is reduced after the mediator is controlled.

\section{Ethical considerations}

Ethical approval to conduct the study was obtained from North-West University (reference number: NWU-0066519-A4).

\section{Results \\ Testing of hypotheses}

The researchers applied Pearson's correlation analysis and multiple regression analysis to test the hypotheses for this study. The results of the correlation analyses are reported in Table 1 . The results showed significant relationships with large effects between job satisfaction, organisational commitment, adult state hope and meaning in life. Significant relationships with medium effects were obtained between job satisfaction and work locus of control and adult state hope and work locus control.

The results of the moderation analyses are reported next.

\section{Moderation analyses}

Multiple regression analyses were carried out to determine the moderating effect of adult state hope, meaning in life and work locus of control on job satisfaction and organisational commitment.

TABLE 1: Results of Pearson's correlation analyses.

\begin{tabular}{|c|c|c|c|c|c|c|}
\hline Variables & Mean & Job satisfaction & Organisational commitment & Adult state hope & Meaning in life & Work locus of control (WLOC) \\
\hline \multirow[t]{2}{*}{ Job satisfaction } & 2.774 & 1 & - & - & - & - \\
\hline & & - & - & - & - & - \\
\hline \multirow[t]{2}{*}{ Organisational commitment } & 2.973 & $0.739 *$ & 1 & - & - & - \\
\hline & & 0.000 & - & - & - & - \\
\hline \multirow[t]{2}{*}{ Adult state hope } & 3.405 & $0.640 *$ & $0.724 *$ & 1 & - & - \\
\hline & & 0.000 & 0.000 & - & - & - \\
\hline Meaning in life & 3.530 & $0.568^{*}$ & $0.718^{*}$ & $0.841^{*}$ & - & - \\
\hline & & 0.000 & 0.000 & 0.000 & - & - \\
\hline \multirow[t]{2}{*}{ Work locus of control (WLOC) } & 3.295 & $0.327 *$ & $0.470 *$ & $0.444^{*}$ & $0.504 *$ & 1 \\
\hline & & 0.000 & 0.000 & 0.000 & 0.000 & - \\
\hline
\end{tabular}

$*, p \leq 0.05$. 


\section{Moderation analysis: Job satisfaction, adult state hope and organisational commitment}

The first step in the moderation analysis reveals a significant positive relationship between job satisfaction and organisational commitment $(\beta=0.795 ; p=0.000)$, indicating that average job satisfaction is associated with average organisational commitment. Job satisfaction explained 54.6\% of the variance in organisational commitment $\left(R^{2}=0.55\right.$; $p<0.00)$. The second step reveals a significant positive relationship between adult state hope and organisational commitment $(\beta=0.78 ; p=0.00)$, an indication that employees with average levels of adult state hope could experience moderate levels of organisational commitment. Adult state hope explained $52.4 \%$ of the variance in organisational commitment $(R 2=0.52 ; p<0.00)$. The third step in moderation with job satisfaction and adult state hope together resulted in a significant positive relationship with organisational commitment $(\beta=0.52 ; \beta=0.48, p=0.00)$. Job satisfaction and adult state hope together explained $65 \%$ of the variance in organisational commitment $\left(R^{2}=0.65 ; p=0.000\right)$. The final step with the intervening variable (job satisfaction $\times$ adult state hope) showed a non-significant result with organisational commitment $(\beta=-0.03 ; p=0.56)$ and no change in the total variance explained $(R 2=0.65 ; p=0.000)$. The results, therefore, showed that adult state hope does not moderate the relationship between job satisfaction and organisational commitment. The results are presented in Figure 1.

In the light of the above results, the researchers applied mediation analyses to determine whether a mediation effect could exist between job satisfaction, adult state hope and organisational commitment. For mediation analyses, values were not centred and steps 1-3 of the moderation analyses were repeated. Only the results of step 4 are reported in the ensuing section.

\section{Mediation analysis: Job satisfaction, adult state hope and organisational commitment}

The final step in the mediation showed that job satisfaction and adult state hope (and its covariates) together explained $65 \%$ of the variance in organisational commitment $\left(R^{2}=0.65 ; p=0.00\right)$. The perceived effect on organisational commitment in step $4(\beta=0.42 ; p=0.00)$ was smaller than in step $3(\beta=0.72 ; p=0.00)$. The effect, however, remained significant, indicating that adult state hope partially mediated the relationship between job satisfaction and

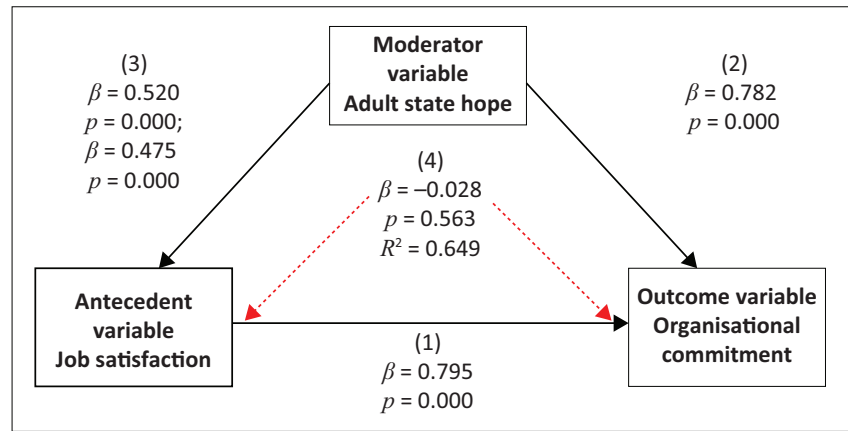

FIGURE 1: Moderation analysis between job satisfaction, adult state hope and organisational commitment. organisational commitment. The results are reported in Figure 2.

\section{Moderation analysis: Job satisfaction, meaning in life and organisational commitment}

The final step (4) with the adding of the interaction variable (job satisfaction $\times$ meaning in life) yielded a non-significant result $(\beta=-0.071 ; p=0.107)$, with a slight increase in the total variance explained $(R 2=0.67 ; p=0.000 ;=67.20 \%)$. Meaning in life, therefore, does not moderate the relationship between job satisfaction and organisational commitment. The results are reported in Figure 3.

\section{Mediation analysis: Job satisfaction, meaning in life and organisational commitment}

The final step (4) in the mediation showed that job satisfaction and meaning in life (and its covariates) together explained $67 \%$ of the variance in organisational commitment $\left(R^{2}=0.67 ; p=0.00\right)$. The perceived effect on organisational commitment in step $4(\beta=0.44 ; p=0.00)$ was smaller than in step $3(\beta=0.72 ; p=0.00)$. The effect, however, remained significant, indicating that meaning in life partially mediated the relationship between job satisfaction and organisational commitment. The results are displayed in Figure 4 .

\section{Moderation analysis: Job satisfaction, work locus of control and organisational commitment}

The first step reveals a significant positive relationship between job satisfaction and organisational commitment $(\beta=0.80 ; p=0.00)$, an indication that lower job satisfaction is associated with lower organisational commitment. The

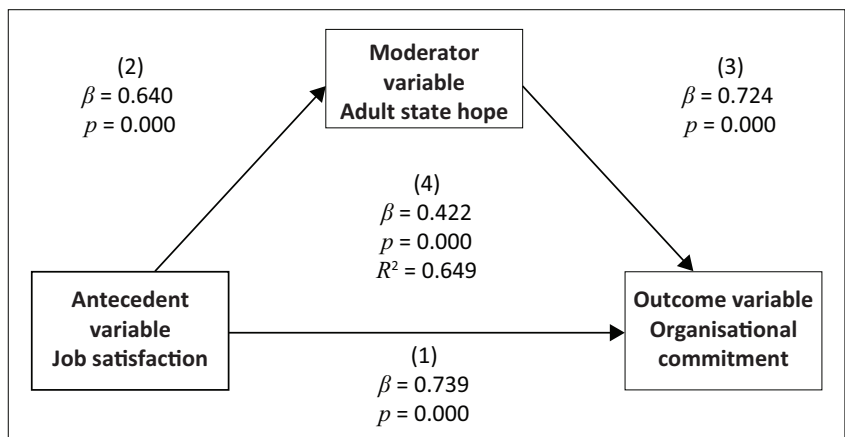

FIGURE 2: Mediation analysis between job satisfaction, adult state hope and organisational commitment.

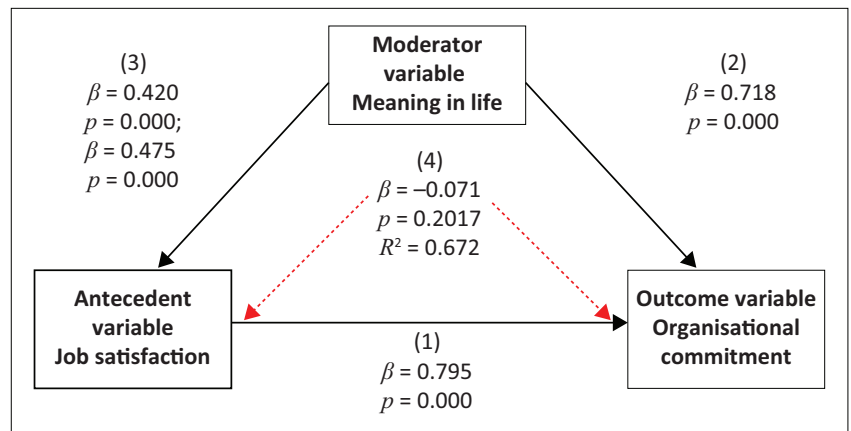

FIGURE 3: Moderation analysis between job satisfaction, meaning in life and organisational commitment. 
second step reveals a significant positive relationship between work locus of control and organisational commitment $(\beta=0.47 ; p=0.00)$, an indication that employees with lower levels of work locus of control will experience lower levels of organisational commitment. Work locus of control explains $22 \%$ of the variance in organisational commitment $(R 2=0.22 ; p<0.00)$. The third step in the moderation analyses shows that job satisfaction and work locus of control (and its covariates) together are significant predictors of organisational commitment $(\beta=0.72 ; \beta=0.26, p=0.00)$ and explained $61 \%$ of the variance in organisational commitment $(R 2=0.61 ; p=0.000)$. The final step with the adding of the interaction variable (job satisfaction $\times$ work locus of control) yielded a non-significant result $(\beta=-0.013$; $p=0.76)$, an indication that work locus of control does not moderate the relationship between job satisfaction and

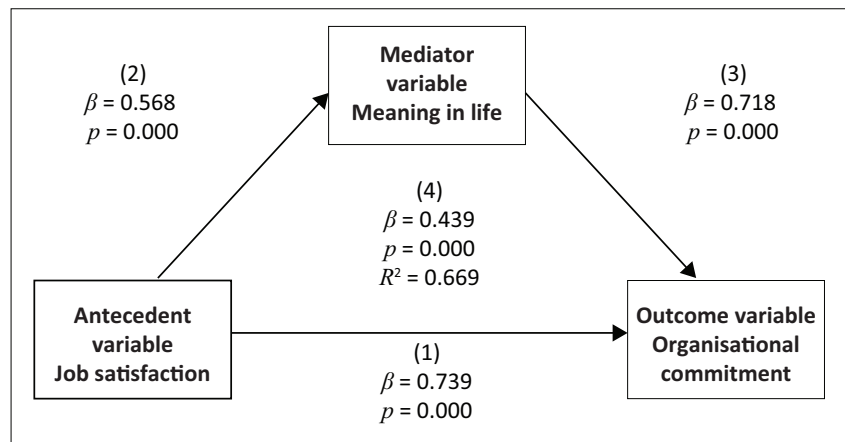

FIGURE 4: Mediation analysis between job satisfaction, meaning in life and organisational commitment.

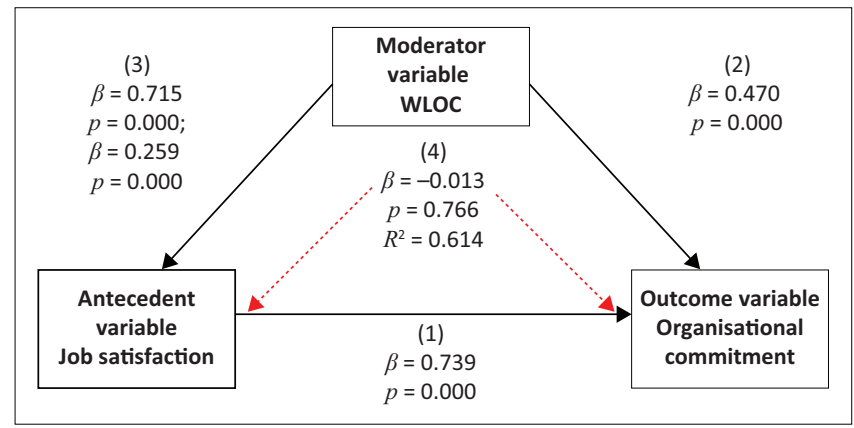

WLOC, Work locus of control.

FIGURE 5: Moderation analysis between job satisfaction, work locus of control and organisational commitment. organisational commitment. The total variance explained remained the same $(61 \% ; R 2=0.61 ; p=0.00)$. The results are reported in Figure 5.

\section{Mediation analysis: Job satisfaction, work locus of control and organisational commitment}

The final step (4) in the mediation analysis showed that job satisfaction and work locus of control (and its covariates) together explained $61.4 \%$ of the variance in organisational commitment $\left(R^{2}=0.61 ; p=0.00\right)$. The perceived effect on organisational commitment in step $4(\beta=0.24 ; p=0.00)$ was smaller than in step $3(\beta=0.47 ; p=0.00)$; the effect however remained positive, indicating that work locus of control partially mediated the relationship between job satisfaction and organisational commitment. The results are presented in Figure 6.

Table 2 provides an overview of the hypotheses that were supported and rejected in this study.

\section{Discussion}

The main objective of this study was to explore how individual traits and psychological strengths (i.e. adult state hope, meaning in life and work locus of control) moderate and mediate the relationship between job satisfaction and organisational commitment. Job satisfaction and organisational commitment have been identified as essential contributors to an emerging country's service performance, such as Botswana (see Berberoglu, 2018; Mkubwa, 2010).

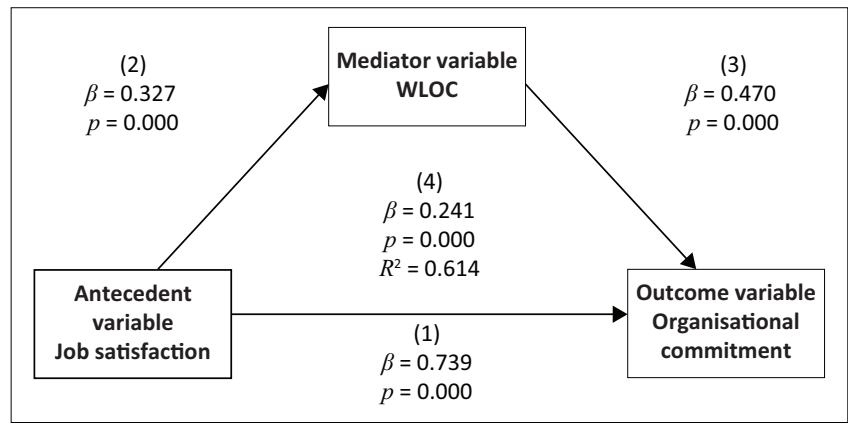

WLOC, work locus of control.

FIGURE 6: Mediation analysis between job satisfaction, work locus of control and organisational commitment.

TABLE 2: Status of hypotheses.

\begin{tabular}{|c|c|c|}
\hline Hypothesis & Hypotheses statements & Status \\
\hline H1 & Job satisfaction is positively related to organisational commitment. & Accepted \\
\hline $\mathrm{H} 2 \mathrm{a}$ & Job satisfaction is positively related to adult state hope. & Accepted \\
\hline $\mathrm{H} 2 \mathrm{~b}$ & Adult state hope is positively related to organisational commitment. & Accepted \\
\hline $\mathrm{H} 2 \mathrm{c}$ & Adult state hope mediates the relationship between job satisfaction and organisational commitment. & Rejected \\
\hline $\mathrm{H} 2 \mathrm{~d}$ & Adult state hope mediates the relationship between job satisfaction and organisational commitment. & Partially accepted \\
\hline H3а & Job satisfaction is positively related to meaning in life. & Accepted \\
\hline $\mathrm{H} 3 \mathrm{~b}$ & Meaning in life is positively related to organisational commitment. & Accepted \\
\hline $\mathrm{H} 3 \mathrm{c}$ & Meaning in life moderates the relationship between job satisfaction and organisational commitment & Rejected \\
\hline H3d & Meaning in life mediates the relationship between job satisfaction and organisational commitment & Partially accepted \\
\hline $\mathrm{H} 4 \mathrm{a}$ & Job satisfaction is positively related to work locus of control. & Accepted \\
\hline $\mathrm{H} 4 \mathrm{~b}$ & Work locus of control is positively related to organisational commitment. & Accepted \\
\hline $\mathrm{H} 4 \mathrm{c}$ & Work locus of control moderates the relationship between job satisfaction and organisational commitment & Rejected \\
\hline $\mathrm{H} 4 \mathrm{~d}$ & Work locus of control mediates the relationship between job satisfaction and organisational commitment. & Partially accepted \\
\hline
\end{tabular}


Moreover, the current COVID-19 pandemic challenges workplaces to rely on positive individual traits, strengths and psychological depositions to sustain an emotionally healthy workforce during an unprecedented crisis.

The results of the study showed average levels of job satisfaction and organisational commitment. From the results, it is plausible that average job satisfaction levels could have contributed to the average organisational commitment levels in this study. However, this finding is open to speculation. More longitudinal studies are required to confirm whether the significant positive relationship between job satisfaction and organisational commitment in this study results from cause and effect. However, the results confirmed previous findings that job satisfaction could significantly influence public sector officials' job satisfaction (see Baruti, 2017; Khan \& Jan, 2014). The results are further explored per research questions formulated for this study.

\section{Job satisfaction, adult state hope and organisational commitment}

The results of the initial multiple regression analyses showed no support for a possible moderating effect of adult state hope in the relationship between job satisfaction and organisational commitment. As an individual trait, hope did not act as a resilience factor to prevent the influence of average levels of job satisfaction on organisational commitment of employees. A follow-up multiple regression analysis partially confirmed a mediation effect between job satisfaction and organisational commitment. In this context, average levels of job satisfaction could partly have contributed to adult hope, which in turn partially influenced organisational commitment (the latter two variables displayed average levels in this study).

The question arises whether hope as a psychological construct is more effective in influencing the direction of the relationship between work-related attitudes (i.e. job satisfaction) and both individual and outcome variables (Luthans et al., 2008) compared with hope operationalised as a trait (Snyder et al., 1996). The absence of research on adult state hope compared with psychological hope and workplacespecific research on hope in general leaves a vacuum that further research studies could explore. The results of this study showed that job satisfaction could contribute positively to adult hope state. An argument is that the type of hope plays an essential role in the job satisfaction-hope relationship. The majority of research studies to date support that hope as a psychological construct contributes to job satisfaction (Brouze, 2013; Luthans et al., 2008). In the present study, job satisfaction was better positioned to influence the respondents' goal-directed behaviour (see Snyder et al., 1996). The results of the study showed that adult state hope had a significant positive relationship with organisational commitment. The researchers can conclude that hope as a psychological construct and trait can significantly influence organisational commitment in a positive capacity (see Bressler, 2010; Pillay et al., 2014).

\section{Job satisfaction, meaning in life and organisational commitment}

As with adult state hope, initial multiple regression analyses rejected the moderating capacity of meaning of life but instead supported a partial mediation effect in the relationship between job satisfaction and organisational commitment. The results partially confirmed the findings of Fletcher and Schofield (2019) that life's meaningfulness can mediate the relationship between micro-level organisational factors and organisational attachment. The limited work context-related research on the intervening role of meaning in life leaves a gap that can be further explored. Available research showed the potential of meaning in life in preventing adverse health outcomes during a crisis, such as COVID-19 (see Schnell \& Krampe, 2020). The results of this research further show that job satisfaction can influence the meaning in life of employees. In support of Rothausen and Henderson (2018), the scope of job satisfaction can be broadened to include a more holistic perspective on the influence of work-related factors on the different spheres of an individual's life. In line with previous research (see Maharaj \& Schlechter, 2007), the results also showed that meaning in life could contribute to organisational commitment.

\section{Job satisfaction, work locus of control and organisational commitment}

The initial multiple regression analyses supported a partial mediation relationship between job satisfaction, work locus of control and organisational commitment. In partial support of Mendoza (2019), a lack of involvement or control over one's environment can mediate the relationship between job satisfaction and organisational commitment. The potential moderating relationship between job satisfaction, work locus of control and organisational commitment was rejected, contradicting the results of Chhabra (2013). Job satisfaction in the present study was positively related to work locus of control. Reknes et al. (2019) and Pourhoseinzadeh et al. (2017) mentioned that employee experiences of work environments could influence their control over their fate, success and failures in life. The results further supported the positive relationship between work locus of control and organisational commitment (see Rank \& Puapradit, 2017).

\section{Practical implications}

This research makes important theoretical, methodological and practical contributions. From a theoretical perspective, at least three important contributions are made. Firstly, the research expands on the limited empirical knowledge about the inter-relationships between job satisfaction, adult state hope, meaning in life, work locus of control and organisational commitment. Secondly, in contrast with most research to date, this research found that job satisfaction can influence hope, meaning in life and locus of control. These results close a gap in research knowledge 
around the direction of job satisfaction in its relationship with other essential individual variables. Thirdly, this research is the first to explore adult state hope, meaning in life and work locus of control in the Botswana context. The research results confirmed the utility of the latter three constructs in the Botswana local government institutions and the potential role that they can play to facilitate job satisfaction and organisational commitment.

From a methodological point of view, the reliability of the measuring instruments was confirmed in the Botswana local government context. The measuring instruments can be used to determine the current level of attitudinal variables (i.e. job satisfaction), personal traits, strengths and personality variables (i.e. adult state hope, meaning in life and work locus of control) and its influence on critical institutional outcomes (i.e. organisational commitment).

The research also emphasise some practical implications that the local government institution should address. This research showed that employee perceptions and attitudes towards their job (i.e. job satisfaction) significantly influenced their organisational commitment. Although the research did not investigate service performance, the importance of job satisfaction and organisational commitment within local government institutions is highlighted elsewhere in this article. Management should, therefore, detect the job-related aspects that contribute to employees' job dissatisfaction as it tends to influence both vital personal level (i.e. meaning in life) and organisational level aspects (i.e. organisational commitment). Managers should also consider employees' unique personal traits and strengths during crises, such as the current COVID-19 situation. Strengthening the adult state hope levels, meaning in life and work locus of control can be a potential catalyst in the relationship between job satisfaction and organisational commitment, as evidenced in this study's partial mediation results.

\section{Limitations and recommendations}

This research had some limitations. The lack of literature on adult state hope, meaning in life, locus of control and its relationships between job satisfaction and organisational commitment challenged the interpretation of the results. The research further focused on a selected government institution in Botswana. Therefore, the results cannot be generalised to other government institutions. A crosssectional research design was adopted, with data collected at a given time. The researchers were limited in determining cause-and-effect relationships between the variables measured in this study. For future studies, the researchers recommend a mixed-method approach to explore the deeper underlying dynamics for the quantitative results. Future research can benefit from determining how attitudinal variables, individual strengths and traits and psychological factors contribute to service quality and performance in the local government context. Finally, the research can also be expanded to other continental and global context to allow for cross-cultural comparisons between local government institutions.

\section{Conclusion}

This research explored how positive individual factors in the workplace context influenced the relationship between work-related attitudes and key institutional outcomes for a local government institution. Our results close the gap in existing empirical knowledge of how adult state hope, meaning in life and locus of control can play a partial role in facilitating the relationship between job satisfaction and institutional outcomes. The outcomes of this research provide promising opportunities for the development of healthy employer-employee relationships in the local government institution by considering the unique contributions of individual traits ad strengths. Therefore, local government managers are encouraged to consider the findings and take corrective actions to ensure a satisfied and emotionally healthy workforce.

\section{Acknowledgements Competing interests}

The authors declare that they have no financial or personal relationships that may have inappropriately influenced them in writing this article.

\section{Authors' contributions}

R.M. compiled the research article and collected the data. E.N.B. provided editorial inputs and assisted with data analyses. N.E.S. and L.v.d.S. provided editorial inputs. All authors read and approved the final version of the manuscript.

\section{Funding information}

This research received no specific grant from any funding agency in the public, commercial or not-for-profit sectors.

\section{Data availability}

The data that support the findings of this study are available from the corresponding author, E.N.B., upon reasonable request.

\section{Disclaimer}

The views and opinions expressed in this article are those of the authors and do not necessarily reflect the official policy or position of any affiliated agency of the authors.

\section{References}

Akhras, C. (2019). Pairing hope and job satisfaction with MENA business leaders Science Journal of Business and Management, 7(4), 74-79. https://doi. org/10.11648/j.sjbm.20190704.11

Aliyu, A.A., Bello, M.U., Kasim, R., \& Martin, D. (2014). Positivist and non-positivist paradigm in social science research: Conflicting paradigms or perfect partners? Journal of Management and Sustainability, 4(3), 79-95. https://doi.org/10.5539/ jms.v4n3p79. 
Andersson, S. (2019, March 10). Ethics management strategies in public organisations the case of Sweden. 2019 Annual Conference of the American Society for Public Administration, Washington, DC

Baron, R.M., \& Kenny, D.A. (1986). The moderator-mediator variable distinction in social psychological research: Conceptual, strategic, and statistical considerations. Journal of Personality and Social Psychology, 51(6), 1173-1182. https://doi. Journal of Personality and Social
$\mathrm{org} / 10.1037 / 0022-3514.51 .6 .1173$

Baruti, T. (2017). Psychological well-being, job satisfaction, and organisationa commitment among employees in Botswana [Unpublished Master's dissertation]. University of the Witwatersrand.

Berberoglu, A. (2018). Impact of organisational climate on organisational commitment and perceived organisational performance: Empirical evidence from public hospitals. BMC Health Services Research, 18(1), 1-9. https://doi.org/10.1186/ s12913-018-3149-z

Bester, J., \& Hofisi, C. (2020). Implementing traditional performance management in the innovative age: A new model for Botswana's public sector. Africa's Public Service Delivery and Performance Review, 8(1), 1-11. https://doi.org/10.4102/ apsdpr.v8i1.392

Bressler, M. (2010). Planning and projecting critical human resource needs: The relationship between hope, optimism, organisational commitment, and turnover intention among US Army reserve soldiers. Journal of Behavioral Studies in Business, 2(1), 1-12.

Brouze, K.L. (2013). Examining the mediating and moderating role of psychological capital in the job demands-resources model [Unpublished Master's dissertation]. University of Cape Town.

Bruininks, Patricia. (2012). The unique psychology of hope. Unpublished research paper.

Buitendach, J.H., \& Rothmann, S. (2009). The validation of the Minnesota Job Satisfaction Questionnaire in selected organisations in South Africa. SA Journal of Human Resource Management, 7(1), 1-8. https://doi.org/10.4102/sajhrm. v7i1.183

Cetin, F., \& Basım, H.N. (2011). Organizational psychological capital: Adaptation study of a scale. Amme Idaresi Dergisi, 1(1), 1-5. https://doi.org/10.4026/13032860.2011.0184.x

Chhabra, B. (2013). Locus of control as a moderator in the relationship between job satisfaction and organisational commitment: A study of Indian IT professionals. Organisations and Markets in Emerging Economies, 4(2), 25-41. https://doi. org/10.1504/IJICBM.2016.078834

Choi, S.H., \& Kang, H.K. (2015). The effects of positive psychological capital on organizational commitment and job satisfaction - The mediating role of positive emotion. Management Information Systems Review, 34(5), 233-249. https://doi. org/10.29214/damis.2015.34.5.012

Cobb-Clark, D. (2014). Locus of control and the labour market, Discussion Paper No. 8678. Bonn: The Institute for the Study of Labour.

Cohen, B.H. (2008). Explaining psychological statistics. Hoboken, NJ: John Wiley \& Sons.

Cohen, J. (1988). Statistical power analysis for the behavioural sciences (2nd ed.) New York: Lawrence Erlbaum Associates Publishers.

Dubale, B.W., Friedman, L.E., Chemali, Z., Denninger, J.W., Mehta, D.H., Alem, A., .. Gelaye, B. (2019). Systematic review of burnout among healthcare providers in sub-Saharan Africa. BMC Public Health, 19(1247), 1-21. https://doi.org/10.1186/ s12889-019-7566-7

Dwivedi, A., \& Rastogi, R. (2017). Future time perspective, hope and life satisfaction: A study on emerging adulthood. Jindal Journal of Business Research, 5(1) 17-25. https://doi.org/10.1177/2278682116673790

Eldor, L. (2018). Public service sector: The compassionate workplace-The effect of compassion and stress on employee engagement, burnout, and performance. Journal of Public Administration Research and Theory, 28(1), 86-103. https://doi. $\mathrm{org} / 10.1093 /$ jopart/mux028

Erwin, C.G. (2011). The effects of locus of control on organizational commitment for chief housing officers [Unpublished Doctoral thesis]. Georgia Southern University

Eslami, J., \& Gharakhani, D. (2012). Organisational commitment and job satisfaction. ARPN Journal of Science and Technology, 2(2), 85-91.

Fagbola, O.O., \& Popoola, S.O. (2015). Influence of locus of control, work motivation and information use on decision - Making of managers in the Aviation Industry in Nigeria. Library Philosophy and Practice, 1(1), 1-28.

Field, A. (2019). Discovering statistics using SPSS (4th ed.). London: Sage.

Fitzgerald, C.S., \& Clark, S. (2013). Work locus of control and perceptions of practice. Journal of Public Child Welfare, 7(1), 59-78. https://doi.org/10.1080/15548732.2 012.738185

Fletcher, L., \& Schofield, K. (2019). Facilitating meaningfulness in the workplace: A field intervention study. International Journal of Human Resource Management [Epub ahead of print]. https://doi.org/10.1080/09585192.2019.1624590

Gangai, K.N., Mahakud, G.C., \& Sharma, V. (2016). Association between locus of control and job satisfaction in employees: A critical review. The International Journal of Indian Psychology, 3(2), 55-68. https://doi.org/10.25215/0302.178

Geldenhuys, M., Laba, K., \& Venter, C.M. (2014). Meaningfulness work, work engagement and organisational commitment. SA Journal of Industrial Psychology, 40(1), 1-10. https://doi.org/10.4102/sajip.v40i1.1098

Giorgi, G., Lecca, L.I., \& Alessio, F. (2020). COVID-19-related mental health effects in the workplace: A narrative review. International Journal of Environmental Research and Public Health, 17(21), 1-22. https://doi.org/10.3390/ ijerph17217857
Gungor, A. (2016). Investigating the moderating effects of optimism, hope and gratitude on the relationship among negative life events and psychological gratitude on the relationship among negative life events and psychological
distress and life satisfaction [Unpublished Doctoral thesis]. University of Central Florida.

Ivtzan, I., Sorensen, E., \& Halonen, S. (2013). The effect of occupational meaningfulness on occupational commitment. International Journal of Psychological Research, 6(2), 15-23. https://doi.org/10.21500/20112084.672

Jada, U., Jena, L.K., \& Pattnaik, R. (2015). Does meaning in life mediate the relationship between hope and organizational commitment: An empirical analysis among IT professionals in India. IMJ, 7(1), 66-77.

Keleş, H.N., \& Findikli, M.A. (2016). The effect of the meaningfulness of work on job satisfaction, job stress and intention to leave. Global Journal of Business, Economics and Management: Current Issues, 6(2), 61-69. https://doi. org/10.18844/gjbem.v6i2.1370

Khan, A., Grema, M.A., Latif, A.B.A., Bahar, H., Iswan, I., Sriyanto, S., ... Panatik, S.A. (2020). Mediating effect of positive psychological strength and study skills on examination anxiety among Nigerian college students. Sustainability, 12(1), 1-16. https://doi.org/10.3390/su12041479

Khan, AS., \& Jan, F. (2014). The job satisfaction of district officers in the developing state of like, Pakistan: A survey of local government of Khyber Pakhtunkhwa. Global Journal of Management and Business Research: Administration and Management, 14(8), 30-18.

Lesenyeho, D.L. (2017). Talent management of early career academics in South African Higher Education Institutions [Unpublished Doctoral thesis]. North-West University.

Locke, E.A. (1976). The nature and causes of job satisfaction. In M.P. Dunnette (Ed.), Handbook of industrial and organisational psychology (pp. 1297-1350). Chicago, IL: Rand McNally.

Luthans, F., Avolio, B.J., Avey, J.B., \& Norman, S.M. (2007). Positive psychological capital: Measurement and relationship with performance and satisfaction. Personne Psychology, 60(3), 541-572. https://doi.org/10.1111/j.1744-6570.2007.00083.x

Magolego, H.M. (2013). The relationship between talent management, job satisfaction and performance in a government institution [Unpublished Masters dissertation] North-West University.

Maharaj, I., \& Schlecther, A. (2007). Meaning in life and meaning of work: Relationships with organisational citizenship behaviour, commitment and job satisfaction. Management Dynamics, 16(3), 24-41.

Martela, F., \& Steger, M.F. (2016). The three meanings of meaning in life: Distinguishing coherence, purpose, and significance. The Journal of Positive Psychology, 11(5), 531-545. https://doi.org/10.1080/17439760.2015.1137623

Mendoza, E.C. (2019). The mediating role of job involvement between job satisfaction and organizational commitment in a small and medium-sized business enterprise. International Review of Management and Marketing, 9(5), 74-81. https://doi. org/10.32479/irmm.8355

Meyer, J.P., \& Allen, N.J. (1991). A three-component conceptualisation of organisational commitment. Human Resource Management Review, 1(1), 61-89. https://doi.org/10.1016/1053-4822(91)90011-Z

Mishra, U.S., Putnaik. S., \& Mishra, B.B. (2016). Role of hope and job satisfaction in stress. International Business Management, 10(9), 1729-1736. https://doi. org/10.17010/pijom/2016/v9i6/94960

Mkubwa, J. (2010). Job satisfaction among public sector physicians in Botswana [Unpublished Master's dissertation]. University of the Witwatersrand.

Morris, R. (2013, June 05-06). Motivating and retaining local government workers: what does it take? The 3rd National Local Government Researchers' Forum, Adelaide.

Moynihan, D.P., \& Pandey, S.K. (2007). Finding workable levers over work motivation comparing job satisfaction, job involvement, and organizational commitment. University of Wisconsin-Madison, The University of Kansas, Lawrence. Retrieved from http://aas.sagepub.com

Mpofu, L. (2013). The relationship between talent management, productive organisational energy and turnover of employees in local government institutions [Unpublished Masters dissertation]. North-West University.

Mukherjee, U., \& Sharma, P. (2020). Hope at workplace: A review of the literature. International Journal of Psychosocial Rehabilitation, 24(6), 5557-5568.

Musekiwa, N., \& Mandiyanike, D. (2017). Botswana development vision and localisation of UN Sustainable Development Goals. Commonwealth Journal of Local Governance, 20(1), 135-145. https://doi.org/10.5130/cjlg.v0i20.6469

Mvelase, N.G. (2018). Exploring the factors influencing employee satisfaction in Msinga Local Municipality [Unpublished Master's dissertation]. Durban University of Technology.

Nalem, L.J. (2015). Factors influencing job satisfaction on employees output. The case of the Tole Tea Estate and the Buea Council. Unpublished Masters Dissertation. Buea: Pan Institute for Development.

Nair, A., \& Manikandan, K. (2013). Meaning in life, organisational commitment and work engagement of employees. Business Sciences International Journal, 1(2), 338-346.

Ozag, D. (2006). The relationship between the trust, hope, and normative and continuance commitment of merger survivors. Journal of Management Development, 25(9), 870-883. https://doi.org/10.1108/02621710610692070

Pillay, K., Buitendach, J.H., \& Kanengoni, H. (2014). Psychological capital, job demands and organisational commitment of employees in a call centre in Durban, South Africa. SA Journal of Human Resource Management, 12(1), 1-13. https://doi. org/10.4102/sajhrm.v12i1.599 
Pourhoseinzadeh, M., Gheibizadeh, M., Moradikalboland, M. \& Cheraghian, M. (2017). The relationship between health locus of control and health behaviors in emergency medicine personnel. IJCBNM, 5(4), 397-504.

Rakowska, A., Valdes-Conca, J., \& Juana-Espinosa, S. (2014). Affecting factors of public employees, organisational commitment. International Journal of Synergy and Research, 3(1), 5-26. https://doi.org/10.17951/ijsr.2014.3.0.5

Rank, S., \& Puapradit, T. (2017). Case study about Germans and Thais: Impact of locus of control and organization-based self-esteem on affective organizationa commitment and job performance. Journal of Intercultural Management, 52(2), 53-79. https://doi.org/10.1515/joim-2017-0008

Reknes, I., Viscockaite, G., Liefooghe, A., Lovakov, A., \& Einarsen, S.V. (2019). Locus of control moderates the relationship between exposure to bullying behaviors and psychological strain. Frontiers in Psychology, 10(1), 1-12. https://doi.org/10.3389/ fpsyg.2019.01323

Rothausen, T., \& Henderson, K. (2018). Meaning-based job-related well-being: Exploring a meaningful work conceptualisation of job satisfaction. Journal of Business and Psychology, 34(10), 357-376. https://doi.org/10.1007/s10869-018-9545-x

Samboma, T.A. (2019). Challenges of Project Implementation in Local Government: The case of Francistown City Council and Kweneng District Council. Working Papers 59, Gabarone: Botswana Institute for Development Policy Analysis.

Sattar, A. (2014). Job satisfaction of district officers: A global perspective. Globa Journal of Management and Business Research: Administration and Management 1(6), 67-80.

Schnell, T., \& Krampe, H. (2020). Meaning in life and self-control buffer stress in times of COVID-19: Moderating and mediating effects with regard to mental distress. Frontiers in Psychiatry, 11(1), 1-16. https://doi.org/10.3389/fpsyt.2020.582352

Shannak, R.O., \& Al-Taher, A. (2012). Factors affecting work locus of control: An analytical and comparative study. Jordan Journal of Business Administration, 8(2), 373-389.

Shaw, W.S., Main, C.J., Findley, P.A., Collie, A., Kristman, V.L., \& Gross, D.P. (2020) Opening the workplace after COVID-19: What lessons can be learned from returnto-work research? Journal of Occupational Rehabilitation, 30(3), 299-302. https://doi.org/10.1007/s10926-020-09908-9

Steger, M.F., Frazier, P., Oishi, S., \& Kaler, M. (2006). The meaning in life questionnaire: Assessing the presence of and search for meaning in life. Journal of Counseling Psychology, 53(1), 80-93. https://doi.org/10.1037/0022-0167.53.1.80

Snyder, C.R. (2000). Hypothesis: There is hope. In C.R. Snyder (Eds.), Handbook of hope theory, measures and applications (pp. 3-21). San Diego, CA: Academic Press.

Snyder, C.R., Irving, L., \& Anderson, J.R. (1991). Hope and health: Measuring the will and the ways. In C.R. Snyder \& D.R. Forsyth (Eds.), Handbook of social and clinical psychology: The health perspective (pp. 285-305). Elmsford, NY: Pergamon Press.
Snyder, C.R., Sympson, S.C., Ybasco, F.C., Borders, T.F., Babyak, M.A., \& Higgins, R.L. (1996). Development and validation of the state hope scale. Journal of Personality and Socia Psychology, 70(2), 321-335. https://doi.org/10.1037/0022-3514.70.2.321
P

Spector, P.E. (1997). Job satisfaction: Application, assessment, causes and consequences. Thousand Oaks: Sage.

Spector, P.E. (1988). Development of work locus of control scale. Journal of Occupational and Organisational Psychology, 61(4), 335-340. https://doi. org/10.1111/j.2044-8325.1988.tb00470.x

SPSS Inc. (2021). SPSS for Windows. Chicago, IL: SPSS Inc.

Tella, A. Ayeni, C.O., \& Popoola, S.O. (2007). Work motivation, job satisfaction, and organisational commitment of library personnel in academic and research libraries in Oyo State, Nigeria. Library Philosophy and Practice, 1(1), 1-16.

Thabo, T.F., Nkhukhu-Orlando, E., Wilson, D.R., \& Forcheh, N. (2018). Factors associated with organizational commitment of academic employees in Botswana. 56-64. https://doi.org/10.5897/IJEAPS2017.0563

Tshukudu, T. (2020). An evaluation of a reward management system used by the Botswana local authority: The Case of Gaborone City Council. International Journal of Sciences: Basic and Applied Research, 50(2), 124-134.

Tummers, L., \& Knies, E. (2013). Leadership and meaningful work in the Public Sector. Public Administration Review, 73(1), 859-868. https://doi.org/10.1111/puar.12138

Volini, E., Schwartz, J., Roy, I., Hauptman, M., van Durme, Y., Denny, B., \& Bersin, J. (2019). Leading the social enterprise: Reinvent with a human focus: 2019 Deloitte global human capital trends. Stamford, CT: Deloitte Development LLC.

Waters, L., Algoe, S.B., Dutton, J., Emmons, R., Fredrickson, B.L., Heaphy, E., ... Steger, M. (2021). Positive psychology in a pandemic: Buffering, bolstering, and building mental health. The Journal of Positive Psychology (Online first), 1-21. https://doi. org/10.1080/17439 760.2021.1871945

Weiss, D.J., Dawis, R.V., England, G.W., \& Lofquist, L.H. (1967). Manual for the Minnesota Satisfaction Questionnaire. Minneapolis, MN: University of Minnesota.

Westmoreland, K., Lowenthal, E., Finalle, R., Mazhani, L., Cox, M., Mwita, J., ... Steenhoff, A. (2017). Registrar wellness in Botswana: Measuring burnout and identifying ways to improve wellness. African Journal of Health Professions Education, 9(3), 98-101. https://doi.org/10.7196/AJHPE.2017.v9i3.881

Yang, X., Fan, C., Liu, Q., Lian, S., Cao, S., \& Zhou, Z. (2019). The mediating role of boredom proneness and the moderating role of meaning in life in the relationship between mindfulness and depressive symptoms. Current Psychology, 38(1), 1-12. https://doi.org/10.1007/s12144-019-00408-5

Zheng, Y., Wu, C., \& Graham, L. (2019). Work-to-non-work spillover: The impact of public service motivation and meaningfulness on outcomes in work and personal life domains. Public Management Review, 22(4), 578-601. https://doi.org/10.108 0/14719037.2019.1601242 